\title{
LIBERTY AND REQUIRED MENTAL HEALTH TREATMENT
}

There are driving forces in man which seek satisfaction. Often these internal drives are conflicting. Man is faced with additional conflict because of the demands made upon him by his surroundings. To reconcile these conflicts he has a mental balancing mechanism. Working at both an unconscious and a conscious level, this psycho-dynamic mechanism seeks satisfaction for the greatest number of internal drives. For various reasons this mechanism may be unable to cope with a particular force so that an individual's action will be dominated by that force rather than governed by a balance. Correcting this inability to balance is the object of mental health treatment.

When should the state require that a person undergo mental health treatment? The answer lies in the goals of a meaningful liberty. The goal of liberty should not be merely freedom from state control or physical confinement. A man lost in the desert has achieved this goal. Rather, a meaningful liberty is the opportunity for each individual to understand and satisfy his needs. For example, a man wishing to recover from a heart attack may have the greatest liberty if he is given the opportunity to be confined in an oxygen tent. Often, however, the needs of different men are in conflict. Thus in a society dedicated to liberty no one man can have absolute liberty. Government and law try to reconcile these conflicts so that the maximum number can have the maximum liberty, i.e., the maximum opportunity to choose goals and to satisfy them.

To the extent that a man's psycho-dynamic mechanism cannot balance conflicting forces, he is unable to satisfy his own wants. To this extent his liberty is diminished. Furthermore, the inability to balance may reduce a person's responsiveness to external demands, such as those made by the law or the needs of dependents. His condition may therefore affect the ability of others to satisfy their wants and to this extent diminish the liberty of others. Thus the results of mental health treatment may increase the liberty both of the patient and of those affected by his condition. Mental health treatment should be required when the increase in liberty resulting from treatment outweighs the limitations necessary for the therapeutic process.

Before molding this principle into a statutory scheme, it will be fruitful to examine the operation of two statutes which represent two current legal attitudes. In 1964 Congress examined the rights of the mentally ill and passed a model statute for use in Washington, D.C. ${ }^{1}$ More recently,

1 District of Columbia Hospitalization of the Mentally Ill Act, D.C. CoDE ANN. $\$ \S 21-351$ to 357 (Supp. IV, 1965), was passed and became effective on September 15, 1964. 78 Stat. 944. Extensive hearings had been held by the Senate in 1961, Hearings Before the Subcommittee on Constitutional Rights of the Senate Comnittee on the Judiciary on the Constitutional Rights of the Mentally Ill, 87th Cong., 1st Sess. (1961), and in 1963. Hearings on $S .935$ Before the Subcommittee on Constitutional Rights of the Sentate Committee on the Judiciary, 88th Cong., 1st Sess. (1963). 
New York, as the result of a Cornell study, revised its laws. ${ }^{2}$ The following case studies are hypothetical situations based on the writer's personal observations of current practices within these two jurisdictions.

\section{Washington, D.C.}

Miss Gatsby was found by the police on a Washington, D. C. bridge. ${ }^{3}$ They thought she was about to jump so they took her to Saint Elizabeth's Hospital: ${ }^{4}$ She was immediately seen by the resident on admissions duty, who talked with her for over half an hour. The doctor asked whether she wanted to stay in the hospital. She replied that she did not, but the doctor decided to hold her for observation. Under the 1964 act the admissions doctor can detain a person in the hospital for forty-eight hours if he determines that the person "has symptoms of a mental illness and, as result thereof, is likely to injure himself or others unless he is immediately hospitalized." 5

After observation of Miss Gatsby in the admissions ward, the hospital filed a petition for a court commitment with the Mental Health Commission. The Commission, which is an arm of the court, ${ }^{6}$ consists of a lawyer, who is a full time chairman, and a pool of eight psychiatrists serving two at a time. It is established for the purpose of making recommendations to the court with regard to allegedly mentally ill persons. ${ }^{7}$ After filing such a petition the hospital can retain a patient during the course of the ensuing proceedings. ${ }^{8}$ The only statutory time limitation for Commission action is that it must "promptly examine" and thereafter "promptly hold a hearing." 9 The current practice is for the Commission to hold hearings at Saint Elizabeth's once a week. ${ }^{10}$

Miss Gatsby was confined to the female admissions ward which consisted of several barren four-bed dormitory rooms and a large lounge with a television set, a table and chairs. ${ }^{11}$ She had been there a week when

2 N.Y. Mental Hygrene Law $\$ \S 70-88$. The law became effective on September 1, 1965. It resulted from a study by the Bar of the City of New York and the Cornell Law School. Spectal Commitree To Study Commitment Procedures of the Association of the City of New York, Mental Illness and Due Process (1962).

3 This hypothetical has been approved as a fair statement. Letter from Arthur J. McLaughlin, Commissioner of Mental Health for Washington, D.C., to the University of Pennsylvania Lawe Revieze, March 24, 1966, on file in Biddle Law Library, University of Pennsylvania.

4 This is a federal psychiatric hospital located on the outskirts of Washington, D.C. It has approximately 6,000 in-patients. There are about seven involuntary admissions brought in each week. The District of Columbia General Hospital has short term psychiatric hospital facilities, and involuntary admissions are sometimes brought there.

5 D.C. Code Ann. \$21-355(b) (Supp. IV, 1965).

D.C. Code ANN. \$21-352 (Supp. IV, 1965).

7 Ibid.

${ }^{8}$ D.C. Code ANN. \$21-355(h) (Supp. IV, 1965).

9 D.C. Code Ann. \$21-356(c) (Supp. IV, 1965).

10 Hearings are similarly held at D.C. General.

11 There are usually about forty-five patients in the admissions ward. They are moved out to other wards at a rate dependent on the rate of new admissions. The 
two doctors and the lawyer from the Commission came to give her an examination. It took five minutes. "Where are you"? "Do you hear voices"? "Does God talk to you"? 12 The next day another lawyer came to visit Miss Gatsby and explained that he was a private attorney who had been appointed by the Commission to see that she got a fair hearing. ${ }^{13}$ They spoke for a while; she did not see or hear from him again until a week later at the hearing.

By the time Miss Gatsby had oriented herself to the hearing room, she realized that the lawyer from the Commission was asking the doctor from the ward to explain what he found to be wrong with her. The doctor read from a paper and concluded that she needed hospitalization. Her assigned counsel then asked whether the doctor had made the examination on which the report was based. The doctor replied that he had just been on the ward two days and had only examined the patient briefly. Most of the report had been based on the hospital record. A Commission doctor asked Miss Gatsby whether she had anything to say. She said she was not going to hurt anyone and asked why were they keeping her locked up. The doctor replied that they were just trying to help her. There was some discussion as to whether she was dangerous. A doctor from the Commission asked her whether she thought she could take care of herself. Miss Gatsby said that her sister could help take care of her. The Commission lawyer asked the assigned counsel whether he had any recommendations. He answered that he was no doctor and that if the doctors thought she needed hospitalization he guessed she did but that he was a little unhappy about the scarcity of medical information. After a short discussion, the Commission decided to continue the case until the next week. ${ }^{14}$ The lawyer was instructed to bring the sister to the next hearing, and the doctor was told to give Miss Gatsby a more extensive examination. Miss Gatsby was returned to the ward.

At Miss Gatsby's second hearing the ward doctor again recommended continued hospitalization, but this time the recommendation was based on his own extensive examination. Miss Gatsby's sister was at the hearing and said she was very busy working and taking care of her two children.

patients are generally confined to the ward. The ward nurse determines roommates according to temperament. The hospital averages about two residents and one staff psychiatrist to each ward. Whether a new patient is given immediate medication varies with the doctors, many choosing to see how a patient reacts for a day or so without medication. Upon being sent to an admissions ward, a patient is interviewed and examined by the resident who will be in charge of him. Most of the patient's day is spent in the lounge and in wandering through the corridors. They have weekly meetings among themselves to discuss ward problems. When possible, nurses and doctors extend ground privileges-freedom to roam the vast hospital grounds.

12 The writer observed ten such examinations, and not one exceeded five minutes.

13 D.C. CODE ANN. \$21-356(d) (Supp. IV, 1965), gives the patient a right to counsel and allows the Commission to recess the case for five days to give counsel an opportunity to prepare. The patient remains in the hospital during such recess.

14 In two days of hearings, this writer observed the continuance used twice. The statute neither prohibits nor expressly permits continuances. It should be remembered that the hospital is free to release the patient at any time without Commission permission. 
The Commission voted two to one for commitment and instructed the lawyer to explain to Miss Gatsby that she had a right to a jury trial if she objected to the Commission finding. ${ }^{15}$ Miss Gatsby accused everyone of being against her and insisted on a trial.

By the time of trial, ${ }^{10}$ Miss Gatsby had been in the hospital almost a month. She had been given the same attention as the other patients. With the help of drugs and a strong desire to win her freedom, she looked and sounded quite healthy. She testified that the whole system was against her, including her lawyer, and that she did not want to hurt anyone. ${ }^{17}$ The Commission doctors also testified in support of their finding. The judge gave the jury a standard charge, stressing that in order to commit her they must make both a finding of mental illness and a determination that she was likely to injure herself or others. He explained that to be mentally ill a person "must have a serious abnormal mental condition; that is . . . [her] mental condition must have departed from the normal state of mind of an average, well-balanced human being." 18 He further charged that injury to others may be from intentional or unintentional acts which "result in harm to others, or cause trouble or inconvenience to others." 19 Finally he explained that " 'to injure himself' may mean that the respondent may be unable to take care of himself and may inadvertently place himself in a position of danger, or suffer harm." 20 The jury was out a short time and returned with a finding that Miss Gatsby was not mentally ill. She was therefore released. If the jury had found for commitment, the court could have ordered "hospitalization for an indeterminate period, or . . . any other alternative course of treatment which the court believ[ed] [would] be in the best interests of such individual or of the public." 21

\section{NEW YORK}

Mr. Carol was persuaded by his employer to accompany him to see a doctor at the Psychiatric Division of Bellevue Hospital. They waited in line for a half hour to see one of the two residents on admissions duty. ${ }^{22}$

15 If the Commission finds that the patient is not mentally ill or not likely to injure himself or others, the patient is immediately released. If it finds for commitment, it must report promptly to the United States district court. If no jury trial is requested, the court makes a determination of such person's mental condition based on the Commission's report and any further evidence it may desire. D.C. CODE ANN. $\$ 21-356$ (e), (f) (Supp. IV, 1965).

16 "If a jury trial is demanded . it shall be accorded by the court with all reasonable speed." D.C. CoDE ANN. \$21-356(f) (Supp. IV, 1965).

17 This writer observed one defendant calmly reading a very well written statement describing the inadequacy of the Commission examination and the lack of assistance from appointed counsel.

181964 Mental Health-CrvIL Commrtment-Jury Instructions 2. These standard instructions are used with slight personal variations by district court judges in the District of Columbia.

19 Id. at 1.

20 Ibid.

21 D.C. CoDE ANN. §21-356(f) (Supp. IV, 1965).

22 The admissions doctors see about fifty people a day. About $20 \%$ object to hospitalization. 
When Mr. Carol was called, the doctor spoke with him for ten minutes. "Do you know where you are"? "What date is it"? "Do you hear voices"? The doctor also spoke with the employer for a few minutes. $\mathrm{He}$ then told Mr. Carol that he ought to stay in the hospital a little while. Mr. Carol said that he knew he was a little confused, but he just wanted to go to his apartment and rest and think things out. He assured the doctor that he would come in for check-ups or take any medicine the doctor prescribed. The doctor decided that since $\mathrm{Mr}$. Carol lived alone he would keep him in the hospital for observation and treatment.

Under the 1965 Revised Mental Hygiene Law, ${ }^{23}$ the standard commitment procedure is to be initiated by certificates from outside physicians. Yet the statutory scheme also makes it possible for the admissions doctor to retain without certificate "for a period of thirty days any person alleged to be in need of immediate observation, care or treatment for mental illness." 24

Upon leaving the admissions office, Mr. Carol was handed a paper which stated his right to a judicial hearing if he so requested. ${ }^{25}$ It also mentioned an information service, which would be available to talk with him about his legal rights. ${ }^{26}$ After becoming oriented to the "ward for the mildly disturbed" to which he was sent, Mr. Carol noticed that a young lawyer came to speak to some of the other patients. He quickly learned that there were three such information service lawyers in the hospital. Recently one patient had been released after the lawyer had her examined by a doctor who spoke her native tongue. If a patient wanted a hearing, the lawyer would make sure that he was represented and that the court had all the relevant information before it. Mr. Carol was told that the judge often listened to the recommendation of the information service lawyer. Furthermore, the lawyers often convinced the hospital to release the patient to the care of a relative without a hearing.

Mr. Carol spoke to the lawyer, who explained how to request a hearing, the standard the judge would use and various other details about the hearing. He asked Mr. Carol to wait a day while he checked with the doctors. The lawyer returned the next day; since it did not appear that his release would be forthcoming, Mr. Carol decided that he wanted a hearing. The lawyer assured Mr. Carol that he would get a hearing as soon as possible and would certainly not have to wait longer than the

23 N.Y. Mentai Hygiene Law \& 72(1).

24 N.Y. Mentai Hygrene Law $\$ 78(1)$. Thus, if in doubt, the resident will commit for observation since he does not have to make a finding of mental illness. All that is necessary is that an allegation be made by the person who brings in the patient.

25 Court hearings are held only if requested by the patient, a friend or a relative. N.Y. MENTAL HygIene Law \&73(1). The hospital can also request a hearing if it wishes to retain the patient longer than the thirty days allowed for immediate observation. N.Y. Mental Hygrene LaW \$78(2).

$26 \mathrm{~A}$ mental health information service is established by statute in each judicial department of the state, and the director of each service is appointed by the appellate division of that department. N.Y. Mental Hygiene Law \$88. 
statutory five days from the time of request. ${ }^{27}$ The court holds hearings at Bellevue two mornings a week. ${ }^{28}$

The lawyer from the information service decided that he would represent Mr. Carol himself. One of the first things that he did was to locate and speak to Mr. Carol's brother. The brother volunteered to let Mr. Carol live with him and his family. He also promised to attend the hearing. Finally, the lawyer made sure that $\mathrm{Mr}$. Carol was given a thorough examination by a doctor who would be able to testify at the hearing.

The hearing procedures are informal; the judge speaks to the patient, listens to the doctors and any witnesses and asks for the recommendations of the information service. ${ }^{29}$ In Mr. Carol's case the service recommended that the judge use his discretionary power under the statute to transfer the patient to care by a willing relative when it appears that such a patient is "harmless." 30 The judge questioned the brother as to the conditions under which Mr. Carol would live. He asked the hospital doctor whether Mr. Carol was considered harmful. The judge decided that Mr. Carol needed continued "retention for care and treatment" and issued "an order authorizing the retention of such patient for care and treatment in the hospital for a period not to exceed six months from the date of the order . . . ." 31

\section{COMMENT}

Before commitment, New York requires a finding of mental illness. However, as stated in the study that led to the New York revision, "Who is mentally ill? Some say all of us. A few say none. We have no pat answer." 32 The study expressed the hope that some day psychiatry would point the way to a more precise definition. But, in the context of commitment proceedings, the question is not one for medical definition. The question is much broader: what state action is most likely to enhance individual liberty? Thus, what is needed is not a medical definition but a procedure

27 N.Y. Mental Hygiene Law § $72(3)$.

28 It is a hearing by the state supreme court; the judges in the city sit at such hearings on a rotating basis.

29 This writer observed hearings before and after the institution of the information service. Before the service was available the judges were mainly concerned that the procedures were being properly followed, notices served, etc., and otherwise almost always followed the doctors' recommendation. One judge commented that it was a "buck passing ceremony."

30 "If, however, it appears that. such mentally ill person is harmless and his relatives or a committee of his person are willing and able properly to care for him, at some place other than a hospital, then, upon their written consent, the court may order the transfer of the patient to the care and custody of such relatives or such committee." N.Y. MENTAL Hygrene LAw \& 72(3).

31 Ibid. Paragraph three of the section indicates that court-ordered retention can be continued by the court for another year after the first six months and for two year intervals subsequently. Section 74 establishes appeal proceedings which include a jury determination of mental illness if desired by the patient, a friend or a relative.

32 Spectal Comamtrtee To Study Commitment Procedures of the Assoctation of the Bar of the City of New York, Mental Illness and Due Process 17 (1962). 
for balancing the numerous medical and nonmedical considerations involved in each case.

Unfortunately, Congress also used the term "mental illness" in an attempt at definition. The statute defines mental illness as any "disease which substantially impairs the mental health of an individual." 33 The imprecision of the term "mental illness" is not narrowed by defining it as the opposite of mental health. Criteria stated in terms of illness, disease or health leave it up to the doctor, judge or jury to make a value judgment as to what is normal or abnormal without providing a standard for making the judgment. ${ }^{34}$ The second phrase of the District of Columbia standard, "likely to harm himself or others," is also not very definitive. What kinds of behavior are considered harmful, and what degree of certainty is necessary for that behavior to be "likely"? The most troublesome aspect of the standard is that it asks for a prediction which depends on unforeseeable future circumstances. One cannot know what future situations the person's life is going to produce. After testifying that a patient was likely to injure herself or others, a Mental Health Commission doctor commented to this writer that he could not be sure what the person would do but that he kept thinking of Lee Harvey Oswald. Since this doctor basically felt that requiring treatment was only being helpful, he had little difficulty in finding that any person who was mentally ill was likely to injure himself or others because of the illness. ${ }^{35}$

No single criterion or definition will adequately express all the considerations relevant to the question of mental health and individual liberty. The following are some of the broad areas for consideration. First, is the patient's refusal to accept treatment itself a result of psycho-dynamic inability to strike a balance? As recognized in many areas of the law, a person's competency to make a choice is relevant to the weight to be given his choice. Secondly, how seriously is the person's liberty decreased by his mental incapacities, and what is the probability that treatment will remove these incapacities? Rather than determining the quantum of mental inability to strike a balance necessary to constitute mental illness, the law should focus on how much the incapacity affects the person's ability to satisfy his desires and how much better he is likely to be able to satisfy his desires after treatment. A third consideration is the effect of a person's mental condition on the liberty of others; for example, the effect of a neurotic wife on the liberty of her husband should be taken into account.

33 D.C. Code ANn. \$21-351 (1) (Supp. IV, 1965).

34 This lack of a standard may well lead to unfair discriminations such as those based on socio-economic class. See Hollingshead \& Redlich, Soctal Class and Mental Illness 194-219 (1964).

35 Another Commission doctor gave a much stricter meaning to the phrase and would only vote for commitment if there were a showing of a strong likelihood of physical injury. He stated satisfaction with such a standard since he was unimpressed with the treatment a hospital could give. 
Also relevant is the amount of restriction necessary for treatment. Realizing that hospital commitment is the most restrictive method of treatment, the full range of socio-psychiatric methods should be considered as possible dispositions. Another consideration is the effect the treatment process will have on the person's liberty. For instance, if a person is so disturbed that if not cared for he will unintentionally starve, then custody in a hospital will increase the person's liberty. A final consideration is the effect the treatment process will have on others. For example, if a mother must be taken from the home for treatment, some thought should be given to the effect on the children of such a course of action.

These are the types of considerations that must be weighed in order to arrive at a solution consistent with our tradition of individual liberty. As information and understanding improve, a more accurate balance between liberty and mental health treatment may be drawn. To establish a system that will best balance these competing factors in individual cases is the task for the law.

\section{A Suggestion}

Any good public mental health program should include a scheme of preventive medicine. Furthermore, the whole public mental health scheme should be geared to inducing voluntary treatment ${ }^{36}$ since (1) a willing patient is more easily treated, and (2) the dictates of liberty suggest that when possible a balance should be struck, in the first instance at least, by those concerned and not by the law. One of the most exciting developments along these lines is the neighborhood service center. There are presently three centers, each located in a storefront, in a highly congested, poverty infested area of the Bronx. They serve a total population of over 350,000 residents. Opening last year, the first two centers gave assistance to 1,400 residents in the first month. ${ }^{37}$ They are run by the Albert Einstein College of Medicine with grants from the city, state and federal governments. ${ }^{38}$ Nearby Lincoln Hospital provides physical and mental health facilities.

The aim of the neighborhood service center program is to develop a mental health program related to the particular problems of slum life. The center is presented to the community as a place where people can bring any type of problem. There is little visual indication that there is any mental health orientation to the centers. ${ }^{39}$ Those who come to the centers need

36 The American Bar Foundation is currently doing a field study of state mental health procedures. One of their preliminary findings is that "many of the practices we observed tend to discourage the use of voluntary admissions . . . American Bar Foundation, Problems in Hospitalizing the Mentally Ill 7 (Research Memorandum Series, No. 31, Oct. 1, 1962).

37 Haliowitz \& Reisman, Progress Report: Neighborhood Service Center Program (1965).

38 The money is from both poverty and mental health funds.

39 The signs in the window indicate help in employment, housing and health problems only. At the time of writing, one center was planning to put up a sign indicating a mental health connection and to assess the reaction. The attempt is to try to make the center as inviting as possible. One center even has plans for an outdoor summer cafe. 
not label their problem before they seek help. In fact defining the problem is one of the major services performed by the center staff. The centers serve as first aid stations for emergency problems in living and guide residents through the morass of public health and welfare services. In addition the centers attempt to stimulate neighborhood pride through various types of group activities which it is hoped will "reduce feelings of powerlessness and inadequacy and increase feelings of independence and autonomy." 40

One of the keys to the success of the neighborhood service center program is the use of nonprofessional aides under the supervision of an experienced professional. "These are people who come from the neighborhood, have experienced poverty themselves and are not sophisticated about mental health problems, but they have a 'savvy' and a 'know-how' that comes out of their experience in learning how to survive." 41 These aides are carefully screened and undergo a six week training program. They seem to know instinctively how to reach out to their neighbors. Many of the clients are Puerto Rican, and the aides literally and figuratively speak their language. "[H]e can intervene directly in the lives of clients on a peer level without resentment. He can make personal friends; he can attend funerals, weddings, baptisms and other social events. $\mathrm{He}$ is a potential companion, counsellor, model and sustainer of hope." 42

These centers are practicing effective preventive psychiatry by helping residents meet the stresses of life. The problems range over the gamut of human misery. The centers try to counter the sense of despair and hopelessness. They also provide voluntary mental health treatment. An actual case will illustrate how the centers function:

Mrs. Jones, a 47 year old widow, came to the Center to seek assistance in urging the New York City Housing Authority to move her to another housing project. She explained that there are two Negro men who live in her building and know that she lives alone and they are awaiting the opportunity to attack her. ...

Amidst tears, she said she was a sick woman. She has had three operations, the last one for cancer and she will shortly have to undergo surgery again. She is convinced that she will die in the next few months and wants her remaining days free from fear and worry. . .

Mrs. Jones relaxed considerably when the Aide told her that she knew how hard it was to live alone and to be alone, particularly when she had to face such trying conditions as having to undergo surgery for possible cancer. . . . With Mrs. Jones'

10 Hallowitz \& Reisman, op. cit. supra note 37 , at 2 .

41 Id. at 8.

$42 I d$. at 9. 
permission, she called Social Service of the hospital where Mrs. Jones was known . . . and arranged for an appointment for Mrs. Jones to talk with the medical social worker. . . . The Aide . . . explained what she had worked out with the social service department and also pointed up to Mrs. Jones her suggestion that the social worker whom she would see would keep in mind whether an appointment with the psychiatrist would be helpful. When Mrs. Jones protested that she didn't need to see a psychiatrist, all she needed was to get another apartment, the Aide responded that she had no question about that, but that she could see, as Mrs. Jones could, that she was very upset and nervous and that psychiatrists were very helpful with these kind of conditions. They didn't see only crazy people. When people get nervous sometimes talking to a psychiatrist was helpful. Also the doctor might be able to give her something to calm her nerves so she wouldn't be as tense as she is now. This seemed to reassure Mrs. Jones and the Mental Health Aide added "Look, if the social worker thinks you are to see a psychiatrist, you don't have to if you don't want to. I think you should. I don't think you have anything to lose. The worst that can happen is that you would lose an hour of your time and the best that could happen is that you might feel better." Mrs. Jones smiled and said, "You are right."

Several days later we learned from social service that Mrs. Jones had been seen by their psychiatrists . . . . The psychiatrist was certain that the depression was reactive to the surgery and the fear of death. . . . He will continue to see her on a weekly basis to provide the necessary support until she undergoes further surgery. ${ }^{43}$

In addition to encouraging and providing facilities for voluntary assistance, this type of community facility should be incorporated into a

$43 \mathrm{Id}$. at $5,10-11$. The following is another example of how the center gives voluntary treatment:

When Mr. Johnson told the Aide that he burns his child's feet with cigarettes as a way of getting him to be obedient the Aide exclaimed, "Man, what did you do that for?" Shock, consternation, and disapproval were clear in the tone. The Aide was not objective, detached, non-judgmental, nor accepting. When the father tried to rationalize that the boy needs to be taught obedience, the Aide agreed, but made it clear that there were other ways to do this and began to talk with him about seeing a child psychiatrist at the Clinic. When the father protested, "But I'm not crazy"; "I'm not saying you are crazy," replied the Aide, "but you're sure doing crazy things. You need help, man." Mr. Johnson was seen by our child psychiatrist and was found not to be psychotic. The child's disobedience had triggered deep feelings of impotence in this father and in desperation and anger he resorted to child abuse. A few sessions relieved the pressure. New coping mechanisms Id. at 12 . were quickly adopted with some promising results. 
mental health statute as part of the required treatment procedure. Such a neighborhood facility would be helpful in all communities both as an initial screening facility and as the major source of information about the patient's environment. It would be especially important in low income areas from which come an overwhelming majority of those who are involved in commitment proceedings. ${ }^{44}$ It is the residents of such areas that least understand mental health treatment and whose way of life is least understood by those who give such treatment. ${ }^{45}$ Besides spreading the case load so that greater attention could be given to each case, the use of the indigenous aide could eliminate many of the problems that come from this lack of communication. In addition, the neighborhood center would make the required mental health service more available to the husband, employer, relative or friend than does a distant reception center or hospital.

Rather than leaving the decision in the untrained hands of a policeman or relative, the statute should make it the center staff's job to determine whether the person should be given psychiatric attention. If the staff determines that such attention is appropriate, then it should be its responsibility to see that the person gets a full examination by a psychiatrist. It might be possible to get private psychiatrists to volunteer time for duty at the center.48 If so, the psychiatric interview could be given right at the center. If not, the center should try to arrange a prompt appointment with one of the private psychiatrists in the area. Perhaps this could be done from a list of doctors who volunteer to take time for center-ordered examinations. When such an appointment is arranged, the center should provide for a responsible friend, relative or volunteer to stay with the person and see that he keeps the appointment. Many times it might be helpful if the aide could go with the person to the interview as a friend, counsellor and interpreter. It could be left to each center to work out these details.

The statute should place the neighborhood centers under the supervision of a mental health commission and make provision for every group of centers to be affiliated with a central short term mental health hospital and clinic. If one of the above arrangements for a psychiatric interview could not be made by a center, then the person should be sent to the central commission facility where the statute would require that there always be a doctor available. Also, the statute should direct that if the center staff determines that immediate custody is necessary and cannot be provided by a friend or relative, it should send such person to the central facility. In other words, if a raving maniac is brought into the center, he should be

44 "It is apparent to me from our studies that we are dealing here primarily with a problem of social welfare. The persons who are committed to state mental hospitals come mostly from the lower classes . ..." American Bar Foundation, op. cit. supra note 36, at 5. See generally HoLLINGSHEAD \& REDLICH, op. cit. supra note 34 .

$45 I d$. at 176.

46 The Philadelphia Psychiatric Society did a study of the volunteer work done by its members. They found that the average member donates fourteen hours per month on professional and community activities. Goldberg \& Myers, Psychiatrists in Action: Myths vs. Facts, 26 DISEASES OF THE NERvOUS SySTEM 375 (1965). 
sent by police or commission car to the central facility. Otherwise, the staff is to try to make arrangements for an examination by a private psychiatrist at the least inconvenience to the person. In this way the person will get more thorough service, by a noninstitutionally oriented doctor when possible, with minimum limitation of his liberty.

The statutory purpose of the psychiatric examination would be to determine whether the person's psycho-dynamic mechanism for balancing internal drives and external demands cannot cope with certain of these forces and, if so, to what extent. Perhaps, for emphasis, the statute ought to indicate that this is a narrower question than whether the person can be helped by psychiatric treatment, for it is reasonable that the examining psychiatrist will believe that he can help anyone who feels he has a problem. The question would also be more meaningful than whether a person is mentally ill for it would not call for a value judgment as to what is normal or abnormal, ill or healthy, but would ask for a factual description of the person's present condition. An experienced psychiatrist should be able to make such a finding in an interview of fifteen minutes to an hour, depending on the severity of the incapacity. The statute should state that if after such an interview the doctor cannot make a positive finding of incapacity, then the problem is not severe enough to justify required treatment. 47

If the doctor concludes that the patient's balancing ability is impaired, then he will recommend treatment. Hopefully the doctor and patient, with the help of the center aide, can come to an agreement on a method of treatment satisfactory to both. The statute should provide that if the patient refuses to accept the doctor's recommendation, then the doctor is to file a recommendation for required treatment with the commission. This should be required to be filed on the day of the examination, and a hearing before a judge should be required five days after its filing. No treatment or custody should be required before the hearing unless the doctor finds both: (1) that no person is capable or willing adequately to care for the patient until the hearing; and (2) that without immediate custody there is a high probability of irreparable harm to the patient or of the patient inflicting physical injury upon others. With the help of the environmental information gathered by the neighborhood center, the above would be more an analysis of the immediate situation than an abstract prediction of future conduct. The statute should make custody the exception, and the center staff should be required to make an effort to find a friend or relative to care for the person.

Before the hearing there should be another statutory examination by another psychiatrist. This would provide the court with two medical opinions. Furthermore, the center staff should prepare, as provided by statute, a report on all relevant social data such as the patient's living con-

47 Interview With Richard Lonsdorf, M.D., Professor of Law and Psychiatry, University of Pennsylvania, February 15, 1966. 
ditions and relationship with relatives or close friends. The staff should also be required to notify-by phone, special delivery letter or in personany known living parents, siblings and spouse of every person for whom a recommendation of required treatment is filed.

A legal service, similar to the New York Information Service, should be connected with the commission. It should be the statutory job of these lawyers to see that the patient's interests are fully presented and that all relevant people and information are present at the hearing. A lawyer from the service should visit and remain in touch with the person for whom required treatment has been recommended as he would a client. He should also contact the neighborhood center staff and examining doctors to listen to what information they have and to suggest what more might be prepared. He should see that the statutory provisions are being properly followed. The lawyer would not be as much an advocate as a legal guide and organizer of the relevant facts. His work should obviate the necessity of a continuance and help the court to strike a fair balance. If the patient wishes, he should be allowed his own lawyer in addition.

The hearings should be informal, similar in form to the hearings presently being held at Bellevue. The statute should instruct the judge first to determine whether the patient is capable of choosing to accept treatment. The examining doctors should be present to give their opinion. If the judge finds that the person is capable of making such a choice, he should be required by law to accept that decision to the extent that it concerns the liberty of the patient. Then, the only further consideration for the court should be the effect of the patient's condition on the liberty of others-i.e., the court should have to find that the person's mental condition substantially interferes with the ability of others to do as they wish before involuntary treatment can be ordered. 48

On the other hand, if the judge finds that the patient is incapable of choosing treatment, he should be free to consider the effect of the patient's condition on both his own liberty and that of others. The judge would probably first listen to the psychiatric report on the severity of the incapacity. Then he would inquire into the full range of considerations mentioned earlier, such as the likelihood that available treatment would remove the patient's limitations, the restrictions that would be necesary for such treatment, the effect of these limitations and the restrictions on the party and on others.

Charged by law with ordering a treatment disposition that has the greatest probability of increasing the opportunity of the patient and all others concerned to lead the lives they desire, the judge should have wide flexibility in fashioning an order. Besides hospitalization, recognition should be given to treatment by regular visits to a doctor, to day care

48 It would be the rare case in which a person with suicidal tendencies and a minimal potential for affecting the liberty of others would be found capable of choosing treatment and thus be released. However, in such a case, this writer accepts the proposition that the person should be allowed to end his own life. 
centers, or to outpatient clinics and to the many other treatment facilities which are rapidly being developed by modern psychiatry and which are less restrictive than hospitalization. For instance, faced with a recommendation that hospitalization would provide the fastest recovery for a mother of two small children, the judge, in striking a balance, might order that private psychiatric treatment be tried first, provided that someone stay with the patient when her husband is not home. Then, if after a certain time the commission still recommended hospitalization, it could file a motion with the court which might be acted upon without another hearing.

It should be the statutory responsibility of the neighborhood centers to see that the court orders are carried out. If the court order requires any treatment, then the commission should have to file a report on the patient's condition with the court every six months thereafter. At that time the patient, or the court, should have the power to require another hearing.

Required mental health treatment is in harmony with our dedication to the principles of liberty, but present commitment statutes do not meet the demands of this dedication. It is hoped that the above statutory scheme will be a framework for a procedure that will give full consideration to the question of individual liberty posed by each case, while restricting the person only as much as necessary during the procedure. 